\title{
USING OF NON-CONVENTIONAL FUELS IN HYBRID VEHICLE DRIVES
}

\author{
Dalibor Barta ${ }^{1}$, Martin Mruzek², Martin Kendra ${ }^{3}$, Pawel Kordos ${ }^{4}$, Leszek Krzywonos ${ }^{4}$
}

1 University of Žilina, Faculty of Mechanical Engineering, Univerzitna 1, 01026 Žilina, Slovakia, e-mail: dalibor. barta@fstroj.uniza.sk

2 University of Žilina, University Science Park, Univerzitna 1, 01026 Žilina, Slovakia, e-mail: martin.mruzek@ uvp.uniza.sk

3 University of Žilina, Faculty of Operation and Economics of Transport and Communications, Univerzitna 1, 01026 Žilina, Slovakia, e-mail: martin.kendra@fpedas.uniza.sk

${ }^{4}$ Lublin University of Technology, Faculty of Mechanical Engineering, Nadbystrzycka 36, 20-618 Lublin, Poland, e-mail:p.kordos@pollub.pl, I.krzywonos@pollub.pl

Received: 2016.08.31

Accepted: 2016.10.08

Published: 2016.12.01

\begin{abstract}
Electric or hybrid vehicles are becoming increasingly common on roads. While electric vehicles are still more or less intended for city traffic, hybrid vehicles allow normal use due to wider driving range. The use of internal combustion engines in hybrid drives is still an inspiration to find the way to reduce the production of emissions. Numbers of alternative energy resources were studied as a substitution of conventional fuels for hybrid vehicles drives worldwide. The paper deals with the possibility of using alternative fuels as CNG, LPG and LNG in combination with hybrid drive of a midibus with the capacity of 20 passengers. Various aspects and techniques of hybrid vehicles from energy management system, propulsion system and using of various alternative fuels are explored in this paper. Other related fields of hybrid vehicles such as changes of vehicle weight or influence of electric energy sources on the total vehicle emission production are also included.
\end{abstract}

Keywords: hybrid drive, alternative fuels, $\mathrm{CO}_{2}-$ emission, simulation.

\section{INTRODUCTION}

An emphasis on technologies ensuring clean environment is greatly demanded of modern cities, where the significant growth of transportation results in increased pollution and other serious environmental problems. The producers of vehicles for public transport introduced electric and hybrid vehicles that minimize the use of combustion engines and its negative effects on environment by integrating them with electric motors [1].

As Mahmoud [3] mentioned, the market share of electric buses has featured steady growth in recent years. In 2012, electric buses had 6\% of new purchases globally [2]. This share is distributed among key players around the world such as Asia Pacific, Europe, and America (South and North).
Several attempts have been made to forecast the potential market share for electric buses; most notable are the efforts of Frost and Sullivan. Ac-

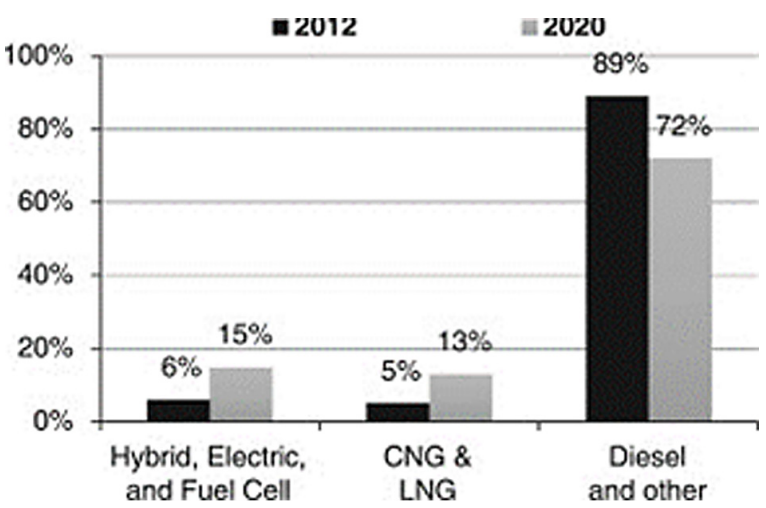

Fig. 1. Global bus market share: new purchases [2] 


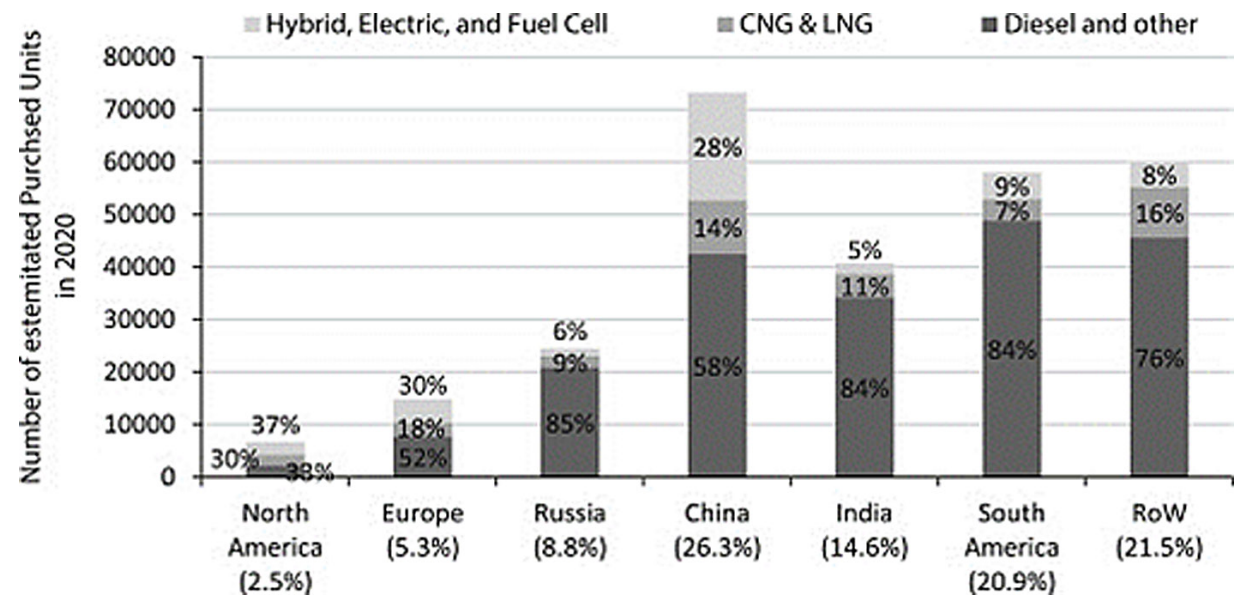

Fig. 2. Distribution of estimated bus market share in 2020 [2]

(between brackets percentage refers to global market share)

cording to their estimates, electric buses will hold $15 \%$ of global market in 2020 with a Compound Annual Growth Rate (CAGR) of $26.4 \%$ as illustrated in Figure 1. However, the market distribution of electric buses shows that the Asia Pacific regions, mainly China and India, will dominate the electric bus market with estimated CAGR of $6.3 \%$. This is compared to $3.9 \%$ in Europe, $3.6 \%$ in North America, and 6.3\% in Latin America as detailed in Figure 2. Taking into account the Asia Pacific bus market share (40.9\%), the estimates show that $75 \%$ of all electric buses will be introduced in Asia Pacific [2, 3].

The greatest challenge in research activities today is developing near zero-emission powered vehicles. Electric vehicles powered by renewable energies offer a possible solution because they only emit natural by products and not exhaust fumes, which improve the air quality in cities and thus the health of their populations [4]. The problem is that most of countries produce the electricity not only from renewable sources, but also from fossil fuels. Composition of primary sources, from which provide electricity in a given country also affects the usefulness and suitability

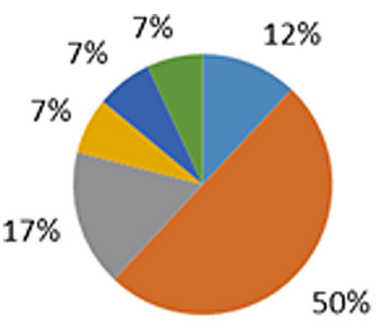

Coal
Nuclear
Wather
nSun
natural gas

Fig. 3. Primary power sources of Slovakia [5] of electric and electric hybrid drives. While in the countries with a high proportion of renewable primary sources of energy (solar, water, wind power stations) the electric drives or electric hybrid drives are well applicable, the use of such drives in countries with a high proportion of electric energy produced from fossil fuels is debatable.

Proportion of individual primary sources of electricity in Slovakia is showed in Figure 3. The main source of electricity in Slovakia is represented by nuclear power plants together with ecological water, solar and wind power stations and only $20 \%$ of electricity is generated by thermal power stations producing monitored harmful emissions. For example in Switzerland, the proportion of electricity generated by thermal power stations is only $5.5 \%$, but in China it is $92 \%$. It means, that the real production of emissions from "ecological drives" (electric and hybrid vehicles) is very different and depends on the proportion of primary sources of electric energy $[5,6,7]$.

Another method to decrease a rising amount of pollution in cities is using alternative fuels in conventional vehicles with internal combustion engines (ICE). It is CNG, LPG or Ethanol, which are most often used as alternative sources of energy for vehicles at this time [8]. The aim of this study is to compare the ecological impact of electric hybrid drives operated with the ICE on the above-mentioned alternative fuels (CNG, LNG, LPG) to electric hybrid drive with the ICE on conventional diesel fuel. The comparison is done from the perspective of production $\mathrm{CO}_{2}$ as a most watched emission of this time.

Combination of various drives usually brings an increase in the total weight of the vehicle. Ad- 


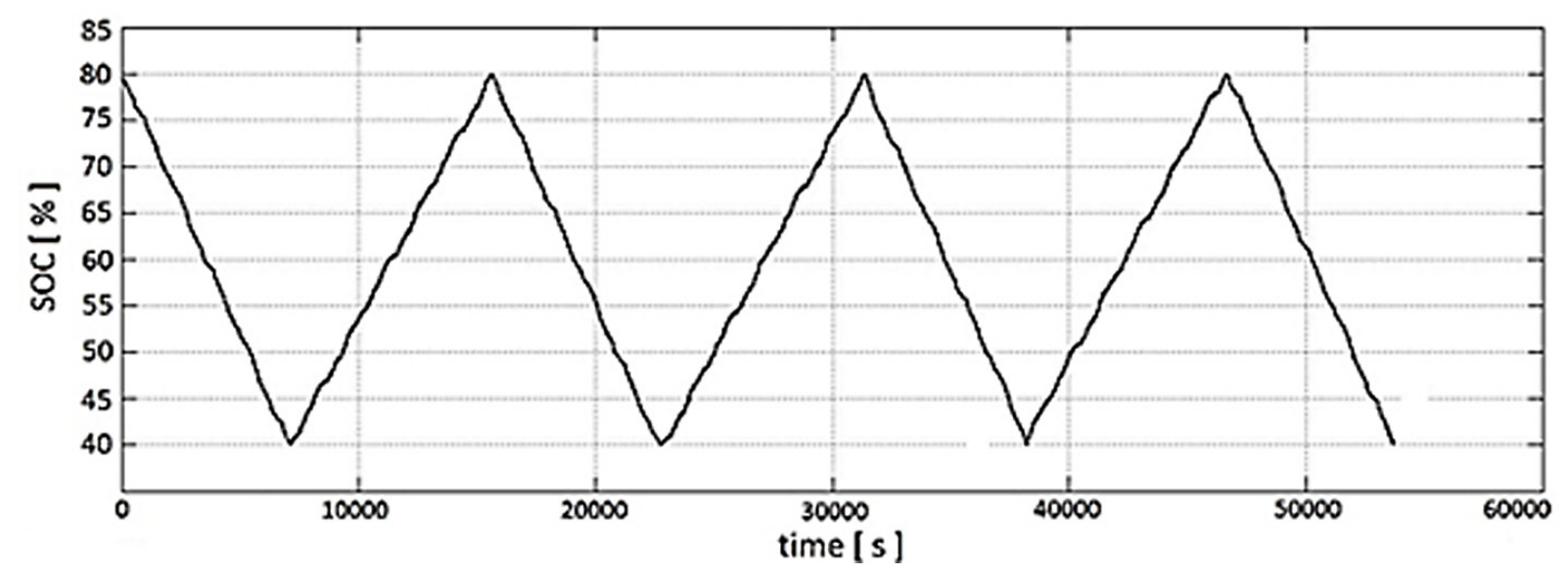

Fig. 4. Course of battery charging [5]

Table 1. Amount of $\mathrm{CO}_{2}$ production by combustion of $1 \mathrm{~kg}$ different fuels [9]

\begin{tabular}{|c|c|}
\hline CNG/LNG & $1 \mathrm{~kg}=2.75 \mathrm{~kg} \mathrm{CO}_{2}$ \\
\hline LPG & $1 \mathrm{~kg}=2.59 \mathrm{~kg} \mathrm{CO}_{2}$ \\
\hline Diesel & $1 \mathrm{~kg}=3 \mathrm{~kg} \mathrm{CO}_{2}$ \\
\hline Gasoline & $1 \mathrm{~kg}=3.2 \mathrm{~kg} \mathrm{CO}_{2}$ \\
\hline
\end{tabular}

ditional weight is caused by tanks for alternative fuels at CNG, LNG or LPG drives and by the weight of batteries at the hybrid and electric drives. Due to different demands on the alternative fuels storage (temperature, pressure) and safety reasons the mass of tanks is variable. It can negatively affect the consumption and emission production in the end. Of course it depends on the volume and weight of the tanks and on the total weight of the vehicle. Therefore, heavier vehicles, for example city buses, with relatively high total weight are most often operated on CNG or LNG, because the weight of additional tanks is not so high comparing to the total weight of the vehicle.

The combustion of $1 \mathrm{~kg}$ of the above-mentioned alternative fuels does not correspond to the same amount of energy of diesel fuel. It means that the fuel doses have to be higher and the final positive ecological effect of these fuels is not always so notable. Table 1 shows the amount of $\mathrm{CO}_{2}$ production by combustion of $1 \mathrm{~kg}$ of different fuels.

\section{BUSES WITH PLUG-IN SERIAL HYBRID DRIVE}

The place where hybrid bus operates has a major effect on the power consumption. Espe- cially elevation profile has the decisive impact. The advantage of the hybrid city bus versus conventional bus is the possibility of recovery of energy when move downhill and braking. The number of intersections where the vehicle has to stop directly impacts the energy consumption [10]. It can be affected by the green waves at traffic lights to ensure the free flow of traffic. Significant impact on the energy consumption of the vehicle also has a density of traffic especially during rush hour. It should be noted that in several cities special lanes for buses to suppress this effect were established. Also green zones, where access by vehicles is limited by their emissions, grow especially in big and green oriented cities. The use of buses with plug-in serial hybrid drives, which are able to cross the green zones in electric local zero emission mode, is useful there.

Public transport buses usually have a fixed route throughout the day and operate by schedule. Distance that the vehicle travels during the day and also the approximate occupancy is therefore known. It is also possible to determine how many kilometres the vehicle needs to pass on pure electric power in the case of green zones, which affects the size and number of batteries. With this knowledge it is possible to configure the hybrid drive to operate as efficiently as possible. One of the assumptions is that the bus will start from the depot with fully charged battery and will return back to the depot with the state of charge (SOC) as low as possible so that the bus can be recharged in depot. This helps to reduce the formation of local emissions in cities, which is highly desirable [5].

Figure 4 shows the intended course of battery SOC when the battery energy is minimal in the end of daily cycle and the bus arrives to the depot [5]. 


\section{SIMULATION OF CO EMISSIONS DEPANDING ON THE BUS DRIVE}

The subject of the simulation was to compare various plug-in serial hybrid bus drives operated on different alternative fuels with the focus on produced emissions. The simulation was performed for three real bus lines 21, 27, 31, operated in Zilina city (Fig. 5). The lines have a different elevation profile and have a different proportion of driving in the city center. Simulation takes into consideration the bus ride by schedule on the above line routes throughout the day. The measurements of input datas for simulation were performed on mentioned lines during rush hours.

The driving of the serial plug-in hybrid bus with total weight of about $5000 \mathrm{~kg}$, depended on the used alternative fuel and on different weight of its tank was simulated. CNG, LNG, LPG and diesel were used as fuels for the simulation. It was calculated with the specific fuel consumption of CNG and LNG $339 \mathrm{~g} \cdot \mathrm{kW}^{-1} \cdot \mathrm{h}^{-1}$, of LPG $335 \mathrm{~g} \cdot \mathrm{kW}^{-1} \cdot \mathrm{h}^{-1}$ and of diesel $255 \mathrm{~g} \cdot \mathrm{kW}^{-1} \cdot \mathrm{h}^{-1}$ [13], [14]. The tank for storage of each fuel corresponds to the stored energy of $1000 \mathrm{kWh}$, what influenced the size of tanks. The differences in tank masses are shown in the Table 2.

Demanded power of the bus hybrid drive train was calculated on the stated conditions by the equation:

$$
P_{\text {dem }}=\left[m \frac{d v}{d t} \lambda+m g(\sin \alpha+f \cos \alpha)+\frac{1}{2} c_{x} S_{x} \rho v^{2}\right] \frac{v}{\eta}
$$

where: $\mathrm{v}$ is the speed of the vehicle, $\mathrm{m}$ is the weight, $\lambda$ is the rotational inertia factor, $\alpha$ is the road angle, $\mathrm{f}$ is the rolling resistance coefficient, $\mathrm{c}_{\mathrm{x}}$ is the aerodynamic drag coefficient, $\mathrm{S}_{\mathrm{x}}$ is the frontal area, $\rho$ is the air density, $\eta$ is the efficiency of the drive, where is included the efficiency of the individual elements of the drive such as electric motor and mechanical efficiency [15].

The power supplied by hybrid unit is composed of power from batteries and power from internal combustion engine via generator.

$$
\boldsymbol{P}=\boldsymbol{P}_{\text {bat }}+\boldsymbol{P}_{\text {ice }}
$$

where: $\mathrm{P}_{\text {bat }}$ is power from battery, $\mathrm{P}_{\text {ice }}$ is power from combustion engine.

$P_{\text {ice }}=0$ when combustion engine is off.

Power provided via recuperation of kinetic energy during braking is calculated by:

$$
P_{r e c}=\left[m \frac{d v}{d t} \lambda+m g(\sin \alpha+f \cos \alpha)+\frac{1}{2} c_{x} S_{x} \rho v^{2}\right] \eta v
$$

Proposed hybrid bus drive control strategy calculates with fully charged battery in the beginning of the day cycle and with charging of the battery from the electricity grid on capacity of $55 \mathrm{kWh}$ during the night. If the SOC falls below the level of $20 \%$ during the bus operation, internal combustion engine (ICE) with proposed power of $100 \mathrm{~kW}$ starts to charge the battery via a generator to its full capacity of $55 \mathrm{kWh}$. 
Total quantity of vehicle emissions produced during the daily cycle results from this simulation. The methodology based on standard emission factors was used for the calculation of emissions production [16]. This value is calculated for each country and includes the overall efficiency of electricity in a particular country, in addition to efficiency of the vehicle. Therefore, this emission factor should be used to compare the country without lengthy search sub efficiency and emissions. Total emissions of vehicles include two components: the emissions from ICE and emissions from electricity production. As mentioned above, it appears that in some countries with a high proportion of environmentally-unfriendly sources of energy is the total emission of $\mathrm{CO}_{2}$ from electric vehicles worser than at conventionally powered vehicles.

Fuel consumption of the hybrid vehicle varies according to the performance requirements given by the route. Due to the using of various alternative fuels with different properties in the simulation, the specific fuel consumption varies and it also affects the amount of produced emissions.

\section{SIMULATION RESULTS}

Results of comparison of total $\mathrm{CO}_{2}$ emissions production simulated for different alternative fu- els on the daily cycle of Zilina lines 21, 27, 31 show Table 3 and Table 4.

It can be seen that in case of using alternative fuels such as CNG, LPG or LPG the production of $\mathrm{CO}_{2}$ emissions is higher than at conventional diesel fuel. It is due to their lower energy content and from this resulting need of higher fuel doses to achieve the same performance. Although, the LNG and CNG is the same fuel - natural gas, stored in liquid or compressed form, there is visible difference in the fuel consumption $(64.66 \mathrm{~kg}$ $\mathrm{CNG}$ to $58.1 \mathrm{~kg} \mathrm{LNG}$ ) and total $\mathrm{CO}_{2}$ emission of the bus (191.68 kg from CNG to $173.64 \mathrm{~kg}$ from LNG) caused by lower weight of LNG tank as seen from the Table 2. The weights of the tanks were determined by producers $[13,14]$.

Detailed comparison of $\mathrm{CO}_{2}$ emission components and total $\mathrm{CO}_{2}$ emissions on Zilina lines 21, 27,31 in the daily cycle simulated for different fuels is stated in Table 4. As seen from the table, the best values of $\mathrm{CO}_{2}$ emissions were achieved with diesel fuel on each line and the worst with CNG fuel. The $\mathrm{CO}_{2}$ emissions of the simulated drive with LPG are usually between these values.

Figures 6, 7 and 8 introduce the changes in total $\mathrm{CO}_{2}$ emissions depending on the used alternative fuel and composition of primary energy sources of electricity in various EU countries. It is visible, that the orange part showing the $\mathrm{CO}_{2}$

Table 3. Comparison of total CO2 production on the Zilina line 21 in daily cycle simulated for different fuels

\begin{tabular}{|l|r|r|r|c|}
\hline Line 21 & CNG & LNG & Diesel & LPG \\
\hline $\begin{array}{l}\text { Fuel consumption on the line cycle 336 } \\
\text { km long }\end{array}$ & $64.66 \mathrm{~kg}$ & $58.1 \mathrm{~kg}$ & $48.3 \mathrm{Lit.}$ & 98.43 Lit. \\
\hline Energy from electrical network & $55 \mathrm{kWh}$ & $55 \mathrm{kWh}$ & $55 \mathrm{kWh}$ & $55 \mathrm{kWh}$ \\
\hline $\mathrm{CO}_{2}$ from fuel & $177.81 \mathrm{~kg}$ & $159.77 \mathrm{~kg}$ & $125.58 \mathrm{~kg}$ & $148.62 \mathrm{~kg}$ \\
\hline $\mathrm{CO}_{2}$ from electrical network & $13.86 \mathrm{~kg}$ & $13.86 \mathrm{~kg}$ & $13.86 \mathrm{~kg}$ & $13.86 \mathrm{~kg}$ \\
\hline $\mathrm{CO}_{2}$ total & $191.68 \mathrm{~kg}$ & $173.64 \mathrm{~kg}$ & $139.44 \mathrm{~kg}$ & $162.49 \mathrm{~kg}$ \\
\hline $\mathrm{CO}_{2}$ in g/km & $570.46 \mathrm{~g} / \mathrm{km}$ & $516.77 \mathrm{~g} / \mathrm{km}$ & $415.00 \mathrm{~g} / \mathrm{km}$ & $483.59 \mathrm{~g} / \mathrm{km}$ \\
\hline
\end{tabular}

Table 4. Comparison of total CO2 production on the Zilina lines 21, 27, 31 in daily cycle simulated for different fuels

\begin{tabular}{|c|c|c|c|c|c|c|c|c|c|}
\hline \multicolumn{9}{|c|}{$\mathrm{CO}_{2}$ emission components } & \multicolumn{4}{c|}{ Total $\mathrm{CO}_{2}$ emissions } \\
\hline Line & Charging & CNG & LNG & Diesel & LPG & CNG & LNG & Diesel & LPG \\
\hline L21 & 13.9 & 177.8 & 159.7 & 125.5 & 148.6 & 191.7 & 173.6 & 139.4 & 162.5 \\
\hline L31 & 13.9 & 317.0 & 300.0 & 239.6 & 284.1 & 330.9 & 313.9 & 253.5 & 298.0 \\
\hline L27 & 13.9 & 388.3 & 374.5 & 307.8 & 348.9 & 402.2 & 388.4 & 321.7 & 362.8 \\
\hline
\end{tabular}




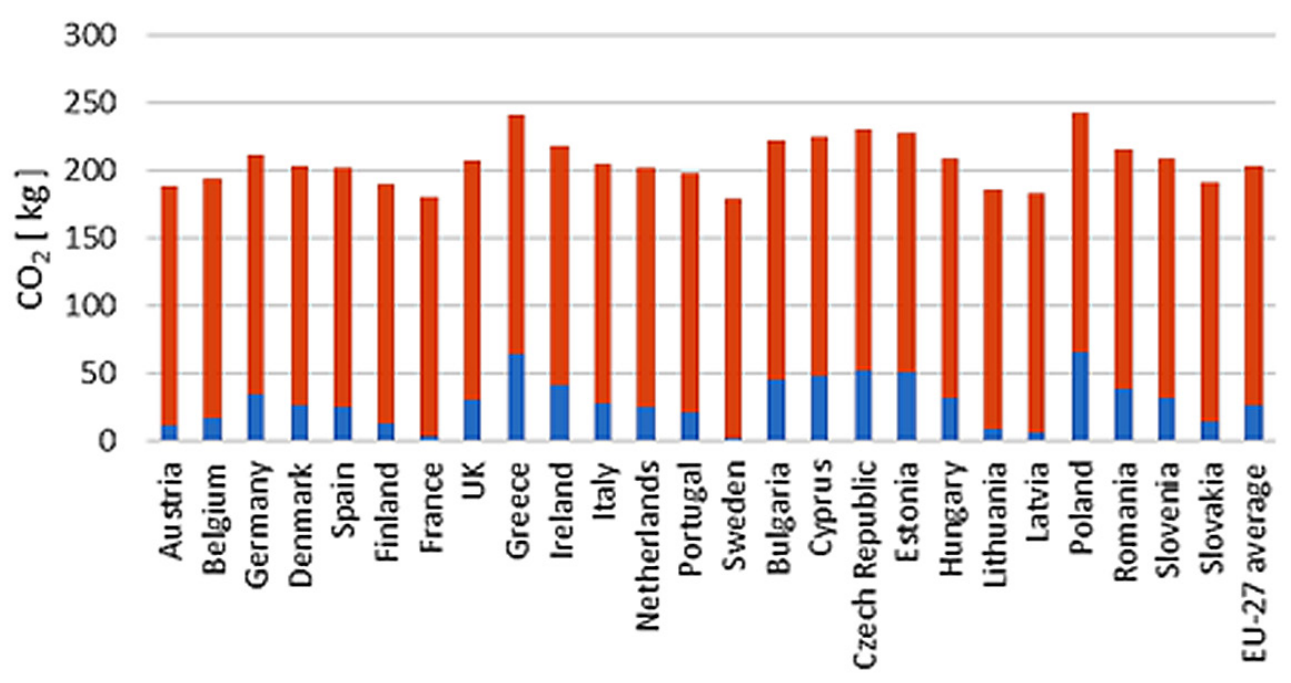

$\square \mathrm{CO} 2 \mathrm{CNG}$

$\square \mathrm{CO} 2$ grid

Fig. 6. $\mathrm{CO}_{2}$ emission produced by $\mathrm{CNG}$ hybrid bus on the daily cycle 21

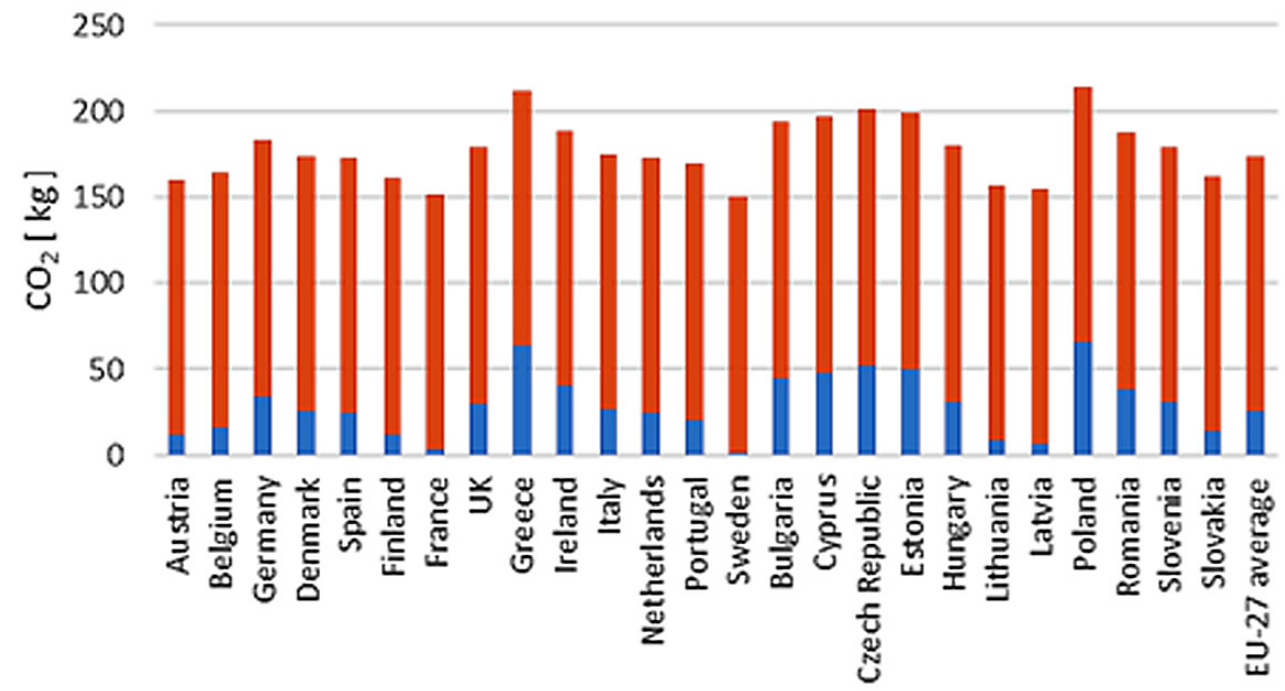

$\square$ CO2 LPG

a $\mathrm{CO} 2$ grid

Fig. 7. $\mathrm{CO}_{2}$ emission produced by LPG hybrid bus on the daily cycle 21

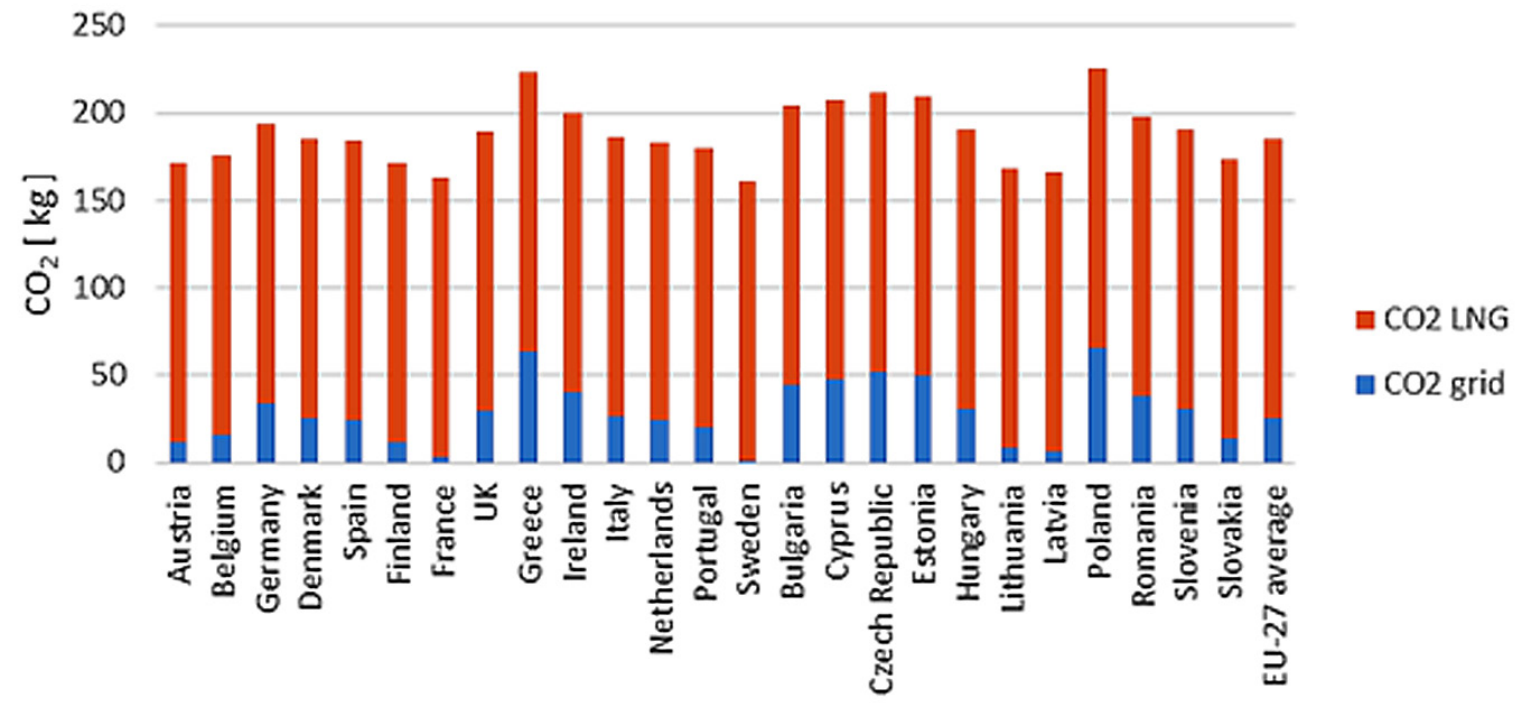

Fig. 8. $\mathrm{CO}_{2}$ emission produced by LNG hybrid bus on the daily cycle 21 
emissions from the ICE is for each country the same and the blue part introducing the $\mathrm{CO}_{2}$ emissions from the electrical grid varies. The best total $\mathrm{CO}_{2}$ emissions were achieved for Sweden and the worst for Poland. In Poland the proportion of emissions from electricity production is 50-times higher comparing to Sweden. It follows that the best justification of using electric and hybrid vehicles is in countries with lower Standard emission factor like Sweden, France, Lithuania, Latvia, Austria or Slovakia. Neither the use of alternative fuels mentioned herein, this state does not change significantly.

\section{CONCLUSIONS}

The simulation mirrors the impact of the composition of electricity sources in various countries on total vehicle emissions. Sweden has the best composition of electric energy sources from the EU countries. Slovakia has also not bad position. Compared to these countries, Poland, Estonia, or Greece have a predominant part of electricity produced from fossil fuels. This fact significantly affects the overall amount of $\mathrm{CO}_{2}$ emissions produced by serial plug-in hybrid bus. It is possible to tell that in some cases the use of plug in hybrid vehicle is ineffective and even worse than using of conventional fuels and drives. There are visible differences in the efficiency of the use of alternative electric drives in various countries.

As it turned out, the using of an alternative fuel in the serial plug-in hybrid bus has no basis in terms of $\mathrm{CO}_{2}$ production, because the specific consumption of diesel engines is lower than engines operating on alternative fuels. This result affects neither the fact that alternative fuels have lower production of $\mathrm{CO}_{2}$ per kilogram of fuel. Mentioned alternative fuels have lower energy content in spite of higher calorific value. To achieve the same power as the internal combustion engine on conventional fuel are needed higher doses of alternative fuels (CNG, LPG, LNG). This is ultimately reflected into the higher total $\mathrm{CO}_{2}$ emission.

As shown by simulation, many factors affect the overall production of emissions of hybrid vehicles. Several factor directly, others indirectly. Because the weight of the bus is relatively high, the difference in weight of tanks associated with using various alternative fuels is not sufficiently important to appreciably affect the fuel consump- tion and thus the total $\mathrm{CO}_{2}$ emissions. The difference in weight of the tank corresponds to approximately 2 or 3 passengers.

As seen from the simulation results, using environmentally friendly components in vehicle propulsion is not always beneficial in all aspects. It can be said that a combination of alternative fuels and hybrid vehicles does not bring any significant advantages over solutions with internal combustion engines using diesel fuel.

\section{Acknowledgements}

This paper was supported by following projects: University Science Park of the University of Zilina (ITMS: 26220220184) supported by the Research\&Development Operational Program funded by the European Regional Development Fund and projects ITMS 26110230107 and VEGA 1/0927/15 - Research of the use of alternative fuels and hybrid drives on traction vehicles with aim to reduce fuel consumption and air pollutants production.

\section{REFERENCES}

1. Jorgensen K. Technologies for electric, hybrid and hydrogen vehicles: electricity from renewable energy sources in transport. Utilities Policy, 16, 2008, 72-79.

2. Frost and Sullivan. Strategic analysis of global hybrid and electric heavy-duty transit bus market (NC7C-01). Frost C Sullivan Publication, New York 2013.

3. Mahmoud M., Garnett R., Ferguson M. and Kanaroglou P. Electric buses. A review of alternative powertrains. Renewable and Sustainable Energy Reviews, 62, 2016, 673-684.

4. Mierlo J.V., Maggeto G. and Lataire P. Which energy source for road transport in the future? A comparison of battery, hybrid and fuel cell vehicles. In. Energy Conversion and Management, 47(17), 2006, 2748-2760.

5. Barta D. and Mruzek M. Factors influencing the hybrid drive of urban public transport buses. Management systems in production engineering, 4(20), 2015, 213-218.

6. Barta D. and Mruzek M. Design of public transport vehicles drive based on real operating parameters. Proc. of 15th International conference on civil, structural and transportation engineering. Ottawa, Ontario, Canada, 2015, 273/1-273/8.

7. Skrucany T. and Gnap J. Energy intensity and GHG production of the road and rail cargo transport using 
a software to simulate the energy consumption of a train. Telematics - support of transport, Katowice/ Kraków/Ustroń, Poland, Berlin: Springer-Verlag, 2014, 263-272.

8. Caban J., Gniecka A. and Holeša L. Alternative fuels for diesel engines. Advances in Science and Technology Research Journal, 7(20), 2013, 70-74.

9. Rotarex. CNG-LPG-H2 compposter-total, 2016, (www.gjt.bme.hu).

10. Siemionek E. and Dziubiński M. Testing energy consumption in the trolleybus and the bus on a chosen public transport line in Lublin. Advances in Science and Technology Research Journal, 9(26), 2015, 152-153.

11. Rimkus A., Melaika M., Pukalskas S. and Nagurnas S. Research of hydrogen influence for gas bus ecological and economic parameters. Proc. of the 16th international conference - Technologija, Transport Means, Kaunas University of Technology, Lithuania, Kaunas, 2012, 13-16.

12. Hlavňa V. et al. Dopravný prostriedok - jeho motor. Transport mean - its engine. University of Zilina, 2007, 466.

13. Autolpg. Velikosti nádrží, 2016, (www.autolpg.cz).

14. Cryo diffusion. Cryogenic cylinder for LNG for taxis, Buses and Trucks, 2016, (www.cryodiffusion. com).

15. Skrúcaný T. and Gnap J. The effect of the crosswinds on the stability of the moving vehicles. Applied Mechanics and Materials, 617, 2014, 296-301.

16. Emisní faktory. Technická př́loha pokynů pro vyplnění šablony SEAP, (www.soglasheniemerov.eu) 